\title{
СТРАТЕГИЧЕСКОЕ ИМПОРТОЗАМЕЩЕНИЕ И ЭКСПОРТООРИЕНТИРОВАННОСТЬ
}

\section{(c) 2020 Коростелев Степан Михайлович}

соискатель кафедры экономики и управления предприятиями и производственными комплексами Санкт-Петербургский государственный экономический университет, Россия, Санкт-Петербург

E-mail: stepan.korostelev@gmail.com

В статье рассматриваются проблемы стратегического импортозамещения как постоянной составляющей процесса развития производства в условиях неоиндустриализации. Утверждается, что современная кампания импортозамещения не носит стратегический характер, что снижает ее эффективность.

Ключевые слова: импортозамещение, стратегическое импортозамещение, ориентация на экспорт.

Реализация торговой политики на современном этапе является проблемой ряда стран и, в первую очередь, Соединенных Штатов Америки. Обсуждение торговой политики в правительственных кругах Вашингтона в последние годы акцентируется на росте торговых барьеров, формировании протекционистских налоговых схем для отдельных отраслей промышленности США с целью роста занятости при создании новых рабочих мест. Естественно, что предварительно правительственные экономисты достаточно полно изучили историю подобных идей, поскольку прямой бездумный перенос идей, реализованных в том или ином государстве, на национальную почву, как правило, не приводил к позитивному результату. Одной из подобных идей, время от времени возникающих в той или иной стране (или же в различные периоды развития экономики государства), является идея импортозамещения как инструмента стимулирования национального производства. В большинстве своем этот опыт не отличался позитивностью, что и было доказано на примере ряда стран, который надо было бы учесть в российских реалиях. Тем не менее, как и каждое экономическое явление, импортозамещение несет в себе как позитивные, так и негативные последствия.

Кстати, именно импортозамещение стало одним из инструментов интенсификации экономики США в период Великой Депрессии. Идея состояла в том, что импортозамещение позволит стране промышленно ускоренно развиваться быстро и уменьшить зависимость от дорогостоящих импортированных товаров промышленного назначения, а использование принципов протекционизма даст возможность внутренним производителям если не полностью избегнуть, то хотя бы ослабить конкуренцию с импортом.

Импортные тарифы были увеличены, были установлены квоты на импорт, и правительства назначили победителей «зарождающейся промышленности» в экономике, субсидируя и защищая определенные ключевые сектора экономики (например, сельское хозяйство, производство капиталоемких товаров, такие как цемент, сталь, алюминий, изделия из бумаги, химикаты, автомобили и тяжелое машиностроение). Правда, это иногда приводило к созданию неэффективных и коррумпированных государственных предприятий в этих привилегированных деловых секторах.

Одним из наиболее ярых сторонников импортозамещения был аргентинский экономист Р. Пребиш, утверждавший, что свободная торговля негативно отражалась на странах-производителях, в частности на Аргентине. По его и других экономистов мнению, в существовавшем на то время экономическом мире, только развитые государства, в частности, США, могли позволить себе переместиться в зону свободной торговли. Другие же государства, зависящие от продажи сырьевых и топливно-энергетических товаров, в свою очередь будут покупать товары промышленного назначения по завышенным ценам. Сам Р. Пребиш называл эту идею «Теория зависимости», что носило несколько марксистский оттенок, хотя это не помешало принять эту идею в основном экономистам либерального характера [1].

Целью реализации теории Р. Пребиша была самостоятельность развивающихся стран, од- 
нако в реальности сам характер реализации его идей привел к еще большей зависимости. К сожалению, страны, проводившие политику импортозамещения в Южной Америке, еще более увеличили импорт промышленных товаров, в то время как товары национального производства будучи неконкурентоспособными на мировом рынке потерял спрос. И именно Аргентина стала ярким примером негативного результата подобной политики. В 1930 Аргентина была одной из 10 самых богатых стран в мире [2]. В 2018 году ВВП на душу населения составил 20567 тыс.долл. (по версии Всемирного банка) [3], и 66 место в мире. Как говорилось выше, сторонники протекционизма в США однозначно утверждают, что американцы стали опасно зависящими от товаров промышленного назначения, поставляемых из других стран, в первую очередь Китая. При этом, на второй план относятся аргументы, связанные с необходимостью роста занятости в США, причем не только за счет переноса производства, ранее размещенного в странах Африки и Юго-Восточной Азии обратно в США, но и за счет прямого импортозамещения.

Тем не менее, проблема не в темпах экономического роста в начальный период проведения политики импортозамещения, а в качестве этого роста, т.е. в структурной трансформации роста с акцентом на развитие систем новых отраслей промышленности на основе высоких технологий или услуг. Кстати, одним из контрпримеров данной ситуации может служить Чили времен Пиночета, когда полностью превалировала либеральная экономика, однако последняя, несмотря на отсутствие барьеров, не смогла остановить падение притока капитала, и страна испытала наиболее глубокий кризис в регионе в 1982-83 гг.

В зарубежной литературе делается вывод, что негативность принимаемых мер заключалось в том, что они были целевым назначением направлены на внутренний рынок (который для ряда стран - Мексики, Бразилии, Колумбии, Аргентины, конечно, был довольно емким) [4], но не на экспорт, что создало отставание по техническому уровню и инновационности выпускаемой продукции ввиду отсутствия внутреннего конкурентного рынка. Государства же Юго-Восточной Азии приняли несколько другую политику, называемую в настоящее время экспортоориентированным импортозамещением. Проблема импортозамещения не в стремлении к росту индустриализации государства, хотя последнее также является одной из целей развития на современном этапе, поскольку позволяет создавать более высокую добавленную стоимость. Тем не менее, как таковая, добавленная стоимость не может являться основным показателем роста, которым стимулируется бизнес.

Одновременно возникает проблема диктата правительством направлений развития рынка, тем не менее правительство, на основании тщательного анализа перспектив развития государства и его роли в глобальной экономике должно обеспечивать стимулы для рынка, чтобы найти, оптимальные решения роста добавленной стоимости, поддерживая одновременно конкуренцию. Неэффективность ряда моделей импортозамещения в долгосрочном периоде связана с тем, что помощь (защита) оказывалась отраслям (видам производств), которые не только не могли, но и не стремились использовать установленные для импорта барьеры, для выхода, в конечном итоге на внешний рынок, т.е. повысить свою конкурентоспособность.

Анализ формирования и реализации российской политики импортозамещения на федеральном, региональном и отраслевом уровнях показывает, что во многом эти действия носили формальный характер (как, впрочем, и ряд мероприятий по направлениям развития, выдвигавшимся как прорывные на тех или иных этапах модернизация, кластеризация, диверсификация и т.п.). При этом основное внимание уделялось не стратегическим аспектам импортозамещения, но решению текущих проблем, связанных с критической ситуацией в тех или иных отраслях промышленности, в первую очередь, обороннопромышленного комплекса. В качестве достаточно яркого примера можно привести, ситуацию, сложившуюся в судостроительном комплексе. Еще в 2016 году утверждалось, что импортозамещение реализуется в соответствии с планами, однако утверждение, что «100\% кораблей Военно-морского флота РФ строится на отечественных верфях и проблем с импортозамещением строительства (как процесса получения готового изделия) военных кораблей нет, поскольку 90\% комплектующего судового оборудования - отечественного производства» [5], опровергалось тем, что ряд агрегатов и деталей производилось на Украине, в странах ЕС, в том числе такие, наиболее критичные позиции, как судовые дизельные двигатели, судовые турбины, 
электрооборудование и др. Неуспехи импортозамещения, на наш взгляд, связано с тем, что во многом управление импортозамещением стало, скорее, политическим аспектом, политики, чем экономическим, поскольку именно с точки зрения политики устанавливаются приоритеты импортозамещения. Как абсолютно правильно писал В.Н. Половинкин, «Целью государственной программы должен быть «экспортный прорыв», а не импортозамещение» [6], тем не менее термин прижился и оснований для его замены, на наш взгляд, нет.

В настоящее время отдельные предприятия, регионы и отрасли в качестве методических материалов по развитию (будем называть его так) экспортоориентированного импортозамещения используют материалы, подготовленные Министерством экономического развития РФ". Возвращаясь к цели кампании импортозамещения, можно отметить, что данные Методические указания не подтверждают необходимость «экспортного прорыва». Так, в п. 4 Методических указаний говорится о том, что «В рамках корпоративного плана импортозамещения рекомендуется определить комплекс мер (перечень мероприятий), направленных на плановое и по- этапное замещение закупки иностранной продукции (работ, услуг) закупкой, эквивалентной по техническим характеристикам и потребительским свойствам отечественной продукции (работ, услуг), исходя из принципов экономической целесообразности и технологической обоснованности (далее - мероприятия по импортозамещению), а также целевых показателей реализации таких мероприятий», т.е., во-первых, говорится только о закупках и практически прямой замены имеющихся зарубежных аналогов российскими, но нет ни слова о приоритетах. Кроме того, даже если необходимые, например, для судостроения силовые машины и агрегаты имеют российское происхождение (что это такое тоже пока окончательно не согласовано), то составляющие их компоненты вполне могут оказаться зарубежными (только сменили, например, страну происхождения). И еще один аспект, который необходимо учитывать в ходе стратегического импортозамещения, это не только замещение производства импортных агрегатов, но и ремонтные работы, ранее осуществлявшиеся (и осуществляемые в настоящее время [7]) зарубежными производителями, владельцами необходимых компетенций.

\section{Библиографический список}

1. Пребиш Р. Периферийный капитализм: есть ли ему альтернатива / Сокр. пер. с исп. под ред. чл.- корр. РАН В.В. Вольского и д.э.н. И.К. Шереметьева. М.: ИЛА РАН, 1992.

2. Мигунов Д. Как Аргентина превратилась из богатейшей страны мира в бесперспективного середняка. https://lenta.ru/articles/2014/01/18/argentina/

3. Список стран по ВВП (ППС) на душу населения. https://ru.wikipedia.org/wiki/\%D0\%A1\%D0\%BF\%D0\%B8\%D 1\%81\%D0\%BE\%D0\%BA_\%D1\%81\%D1\%82\%D1\%80\%D0\%B0\%D0\%BD_\%D0\%BF\%D0\%BE_\%D0\%92\%D0\%92\%D0 \%9F_(\%D0\%9F\%D0\%9F\%D0\%A1)_\%D0\%BD\%D0\%B0_\%D0\%B4\%D1\%83\%D1\%88\%D1\%83_\%D0\%BD\%D0\%B0\%D 1\%81\%D0\%B5\%D0\%BB\%D0\%B5\%D0\%BD\%D0\%B8\%D1\%8F

4. Baer, Werner (1972), Import Substitution and Industrialization in Latin America: Experiences and Interpretations, Latin American Research Review vol. 7 (Spring): 95-122.(1972)

5. Судостроение наше: 100\% кораблей ВМФ РФ строится на родных верфях. https://rueconomics.ru/175474importozameshchenie-v-sudostroenii-100-korablei-vmf-rf-stroitsya-na-rodnyh-verfyah

6. Половинкин В.Н. Проблемы импортозамещения в области судового машиностроения и приборостроения. Меры по снижению их негативного воздействия. http://in-space.info/news/problemy-importozameshcheniyav-oblasti-sudovogo-mashinostroeniya-i-priborostroeniya\#

7. Импортозамещение буксует: украинское предприятие остается монополистом по ремонту газотурбинных двигателей в России. https://flotprom.ru/2019/\%D0\%98\%D0\%BC\%D0\%BF\%D0\%BE\%D1\%80\%D1\%82\%D0\%BE\% D0\%B7\%D0\%B0\%D0\%BC\%D0\%B5\%D1\%89\%D0\%B5\%D0\%BD\%D0\%B8\%D0\%B521/

8. Бодрунов С.Д. Теория и практика импортозамещения: уроки и проблемы: монография / С.Д. Бодрунов.СПб.: ИНИР им. СЮ. Витте, 2015.-171 с.

\footnotetext{
"Методические рекомендации по подготовке корпоративных планов импортозамещения государственными корпорациями, государственными компаниями, акционерными обществами, в уставном капитале которых доля участия Российской Федерации превышает 50 процентов, организациями, реализующими инвестиционные проекты, включенные в реестр инвестиционных проектов в соответствии с решением Правительственной комиссии по импортозамещению.
} 